\title{
Reflection of Religious Intolerance Myth in Video Construction "Sayyid El-Rais" Based on Barthes Perspective
}

\author{
Ifi Erhintiana \\ UIN Sunan Kalijaga \\ ifierwhintiana@gmail.com \\ Laily Fitriani \\ UIN Maulana Malik Ibrahim \\ laily@bsa.uin-malang.ac.id
}

\begin{abstract}
This research aims to develop denotative and connotative meanings in sayyid El-Rais' videos, as well as reveal myths based on Barthes's perspective. This research is a qualitative descriptive research. Data collection technique used observation and taking notes technique. Researchers used descriptive analysis techniques based on the Miles and Huberman model are data reduction, data presentation, and conclusions. The results showed that reading of first level in semiotics perspective produced several codes that referred to text structure including; symbolic, semantic, and hermeneutic. Denotatively, the speech in video reflect outpouring of a Palestinian child about incidents that happened to him, called deprived homeland. The second level reading that refers to code development resulted in a myth of religious tolerance. In connotative meaning, there are portraits of religious intolerance that are carried in these stories. This speech presents as religious intolerance representation felt by the Palestinian people so that the author's message that can be taken through this portraits is able to increase awareness of religious tolerance and empathy for others as humanity form.
\end{abstract}

Keywords: Barthes's semiotic, myth, palestine, religious intolerance

\section{INTRODUCTION}

Today, literature is increasingly required to keep up with the times. In the digital era, humans are faced with technological advances where critical abilities are tested to adapt with novelty. Likewise with literature, as a reflection of reality about society, of course, it must adapt to existence developments. In this context, literature cannot be separated from society because literature reflects social dynamics which occur in society. As well as other literature, the development of Arabic literature marked by the Arab Spring where literary works began to be printed and published. Not only that, but literature is also distributed through social media including YouTube. Nowadays YouTube is one of the popular platforms for distributing literature because it makes literature easier for the public to consume it.
Talking about literature and media, literature is a medium for self-expression in expressing one's imagination and ideas substantially. In addition, through the media, literature is believed to be able to build social awareness with the aim of change and even resistance. why literature has the hidden ability to influence feelings and thoughts. As same as one of video clips on the youtube channel under title Sayyid el-Rais.

Sayyid el-Rais is one of viral video clip on YouTube in May 2018. A video with Ramadhan theme has drawn much controversy, because it is considered provoking several parties. This video is about 3 minutes 39 seconds and published by Zain Entertainment. Now, this video has 49 million viewers with 1.2 million likes and 122 thousand comments (Youtube, 2018). It showed that this video is enough to attract the attention of audiences as consumers. As well as reported 
by Detik.com, this video presents a portrait of a boy who invited some world leaders for breakfast (Rosyadi, 2018).

Based on the phenomenon above, many netizens responded positively to this video. For them, the message conveyed is very touching because this video is considered to speak for Palestine. But on the other side, many people considered this video as a form of provocation that cornered several parties, especially the portraits of characters shown in the video clip. This phenomenon makes researchers interested in examining more deeply the intent behind this video. In this context, researchers think that this video is very suitable to be analyzed with Barthes' concept of myth. Based on the semiotic review, Barthes is based on the principle that cultural aspect is very valuable in a semiotic process. That's why Barthes presents the concept of "myth" in his semiology.

Semiotics exists as a branch of sign-focused linguistics. In simple terms, semiotics wants to know how humans interpret things. Teuw defines semiotics as a sign that involves all factors to understand literature as a medium of communication (Sobur, 2018, p.17). According to historical review, semiotics is pioneered by two great figures, they are Ferdinand De Saussure and Charles Sanders Pierce. Both of them have different backgrounds where Saussure in Europe and he departed from linguistic. Meanwhile, Pierce came from Latin America and departed from philosophy. Seeing its development, both of them have their own characteristics which Saussure calls the study of signs with the term "semiology", but Pierce calls it by the term "semiotics" which is considered to be more popular today (Vera, 2014, p.100).

\section{Barthes Mythology}

Roland Barthes as a structuralist and also a Saussurian who developed the concept of semiosis. Barthes found a systematic analytical model in describing signs (Birowo, 2004, p.45). In this context, he focused on the concept of significance. Barthes believes that relationship between marker and marked is formed arbitrarily
(Vera, 2014, p.27). This concept begins from Ferdinand De Saussure's interest about complexity of sentence formation in determining meaning. However, Barthes developed this thought and emphasized that there is an interaction between texts and individual cultural and personal experiences, as well as interactions between text conventions and their users. This concept is known as "order of signification" (Kriyantono, 2006, p. 268).

As suitable as Barthes' basic assumption showed that language as a sign system is able to reflect the assumption of certain group in certain period (Vera, 2014, p.26). Based on the concept of "order of signification", Barthes pays attention to significance that is classified into two steps, namely first order of signification and second order of signification (Birowo, 2004, p.56). Here are the difference between the concept of Barthes and Saussure where Barthes divides the level of meaning into denotation and connotation or meta-language.

Barthes explains denotation as a simple signification process that refers to textual meaning. In this step, signs are produced and understood at the first level of meaning, known as the first order (Sobur, 2006, p.70). This level produces the most obvious explicit meaning of sign (Vera, 2014, p.57). It is different from the connotation which becomes the second signification process when the sign develops expression aspect (E) and obtains expansion of Content (C) (Rusmana, 2014, p.203). This level produces implicit meaning, indirect meaning, and uncertain. The creation of connotation meaning is motivated by combination of marker and marked that touched cultural aspects. That's why the connotation meaning is arbitrary depending on the interpreter (Sobur, 2006, p.128).

Based on Barthes' semiotics, connotation meaning is aligned with an ideology known as "myth". According to him, the marker and marked in connotation meaning are ideological fragments, establishing relationship between communication and culture, also knowledge and history (Rusmana, 2014, p.207). In this context, the definition of myth is indeed different from 
the general meaning which identical with mystical things. Barthes defines myth as a connotation formed by society in symbols form and being interpreted by society itself (Sobur, 2006, p.71).

Myth is defined as a type of speech, so that all speech, both verbal and non-verbal, have the potential to become a myth (Barthes, 1973, p.95).In his book "Mythologies", Barthes illustrates myth with glasses. People with glasses are synonymous with intelligent but an innocent one. Meanwhile, people who wear glasses are exactly someone with visual disabilities. In this context, glasses mean a visual aid. However, it is different if it draws in the mythical universe, glasses are considered to show someone's intelligence. Culturally, the glasses are accepted by society as a symbol of genius, so that glasses are emphasized (Hidayat, 2018, p.177). Thus myth can be aligned with connotation meaning where cultural elements have a dominant role.

\section{Tolerance Concept}

Religion exists not only as a medium for human interaction with God, but also to regulate relationship among humans, as well as the surrounding environment. That's why, tolerance becomes important for every human being on this earth. The existence of tolerance can minimize the occurrence of conflict and replace it with a life of peace and tranquility.

Looking at the historicity of tolerance concept, it is necessary to have understanding of tolerance itself holistically. Tolerance in etymological meaning is graceful. As same as definition in the Big Indonesian Dictionary that tolerance comes from word "tolerant" which means to let, respect or take a different stance as before (Kamus Besar Bahasa Indonesia, n.d.).As same as Arabic term, it means tasamuh, to let (Munawir, n.d. p.1098). In other words, tolerance can be defined as generous attitude towards something deviating from usual.

In terminology terms, there are several definitions according to experts, including Umar Hasyim (1979, p.22) defines tolerance as a form of giving freedom in exercising faith, and managing life even determining fate, but still in accordance with prevailing societal provisions. It different from Tillman (2004, p.95) that defines tolerance as an attitude of mutual respect by each individual to plurality.

Based on the definition of tolerance, simply tolerance is an attitude statement that has a positive impact on society. According to historical reviews, the emergence of tolerance cannot be separated from religious backgrounds. In the context of religion, tolerance is always an interesting topic to discuss. Unfortunately now, when faced with the condition of Islam, there is an assumption that Islam is identical to intolerance, extreme and discriminatory (Bakar, 2015, p.124).

Based on Western historical reading, tolerance has known since early 17 th century as emergency concept in overcoming differences and bloodshed due to religion (Nicholson, 1985, p.156). One of the most famous founding father of tolerance concept in West is John Locke. Through his work "A Letter Concerning Toleration", he emphasized that a country must refrain from political authority involving religious beliefs (Goldie, 2010, p.32). In this context, Locke emphasized that tolerance only applies to religious owners, so that atheists do not need accept tolerant attitudes.

In religious context, disagreement views often lead to conflicts, even wars (Ismail, 2003, p.169). That's why tolerance is urgent, especially in democracy foundation where each individual can hold his or her opinion and respect others (Obsorn, 1993, p.11).

As long as time development, tolerance concept also expanded. Tolerance is not limited to respect, but an ethical framework that is intended to respond differences (Nicholson, 1985, p.159).Various experts develop tolerance concept, but there should be limitations on definition of tolerance itself. In other words, tolerance is not a doctrine for respecting others without limit until all freedom can be celebrated out of control (Horton, 1985, p.4).

Talking about the limits of tolerance, of course it related to the question about how extent tolerance is allowed and said to be intolerant. As well as tolerance is defined as freedom, it extents 
to how the freedom can be celebrated. In this context, borrowing Karl Popper's concept which asserts that the loss of tolerance when tolerance becomes infinite. In other words, if this tolerance applies to intolerant people, then that person will be destroyed because of his tolerance (CohenAlmagor, 2006, p.1). Therefore, it is needed to be more attention to intolerance as vigilance form in overcoming tolerance issues.

Based on its implementation, there are tolerance elements in certain society including; 1 ) giving freedom as protecting individual and collective freedom with available regulations, 2) recognizing eveyone right in attitudes, 3) respecting beliefs of others who tend to be religious, but it can also be linked to social contexts, 4) mutual understanding and respect each other either individually or collectively (Abdullah, 2001, p.202).

Based on the explanation of tolerance concepts and its elements, it is increasingly clear that the meaning of tolerance cannot be equated with neutrality which is almost similar to impartiality. Because of tolerance is not indifferent, so it can openly accept criticism or suggestion as known as "critical tolerance" (Masduqi, 2011, p.9). Thus, tolerance is very easy to apply in creating unity without overlapping each other.

As well as explanation above about suitability of phenomenon and theory, this research refers to several previous studies including; Representation of Ideological Meaning in Story "Ashab Al-Kahf" (Hidayat, 2018, pp.170); Semiotic Analysis of Roland Barthes; Islamic Perspectives on Moral Values in the short story "Daulah Ashafir" by Taufiq Al-Hakim (Semiotic Analysis of Roland Barthes) (Nugraha \& Kasanah, 2019, pp.76); Representation of Mascunility in Pond's Men \#Lelakimasakini Television Advertisements (Roland Barthes' Semiotic Analysis of Representation of Personality) (Yulianti, 2017, p.16).

Based on the relevance between material object and formal object, the researcher intends to further describe geopolitical myth in the video clip of Sayyid el Rais based on Barthes' perspective. This article aims to reveal the form of geopolitical myths and the ideological concepts that are carried in the video.

\section{METHODOLOGY}

This article is a qualitative descriptive research which used to examine the conditions of natural objects. In this context, the researcher as key instrument, sampling of data sources is carried out purposively, and the results of research emphasized generalization aspect of meaning (Sugiyono, 2008, p.15).

In obtaining valid data and suitable with expecting data, data collection techniques used in this study are watching and taking notes (Sugiyono, 2008, p.208). The data collected will be analyzed using descriptive analysis based on the analysis model according to Miles and Huberman. It contained in Sugiyono's book which states that Miles and Huberman argued that "activities in qualitative data analysis are carried out interactively, and continued to completion so that data is saturated. These activities are informed of the data reduction, data display, conclusion drawing or verification (Sugiyono, 2008, p.337). Thus the result of data analysis will be presented descriptively and be concluded as suitable as research problems contained in this study.

\section{RESULT AND DISCUSSION}

As previously explained regarding the level of meaning based on Barthes perspective which includes denotation meaning as first reading level (First-ness), then connotation meaning as second reading level (second-ness), and the last one is myth (ideology). The more detailed explanation as follows:

\section{Barthes' Significance}

In this sub-chapter, researcher describes first level of meaning, namely denotation level where a text is interpreted autonomously or free from extrinsic elements of literary work. In this context, linguistic aspect plays very important role where speech is interpreted as it is without other elements. This study seeks to implement Barthes semiotics in sayyid el-Rais' video. In this 
context, video is positioned as a linguistic phenomenon, so this study focuses on speech contained in the video. The more detailed explanation is as follows:

$$
\text { و و ريدي الرئيس مدعو على الإفطار }
$$

The speech above shows an invitation. Structurally, sentence is an invitation sentence that is marked by nida' at the beginning of sentence, it is "sayyidi rais". The denotation meaning appears in the speech above is a call belong to president by saying, "O President, Ramadan arrived, I invite you to fast with me. This speech is also supported by the context of a boy who walked towards a table that is none other than the office of United States president, called the white house and invited President Trump to fast together with him. The denotative meaning obtained from speech above is purely a verbal invitation to fast together with him. This is suitable with Barthes's concept of denotative meaning which explains that at this level of significance process naturally refers to a literal meaning, so it does not require other elements outside the text.

It is different if the speech in second level meaning that called connotative. Of course, this speech expanded its meaning. In other words, there is an implicit message that author wants to convey. It can be proven by the following two sentences which read:

$$
\text { و عادت أمي من الطابور بخبز وفلي الدعام كسور }
$$

The piece of speech above shows that marker is a destroyed house and symbolizes a pessimistic attitude. While the sign in question is destroyed house. Of course, it cannot be used for any activity, including fasting. Here then connotation meaning that child wants a feeling of peace and comfort in life, especially in harmony among people. This is also confirmed by sentence that follows which describes the condition of his mother whom carrying bread and a broken heart. This speech clearly shows the dashing of one's hopes for a life in peace and safe. As suitable as context shows Trump's deep lament when he said it directly in front of him, but Trump just turned his face away without answering.

As well as Barthes's statement explains that connotation meaning is formed based on individual beliefs in interpreting phenomenon (Sobur, 2018, p.70).Thus, connotation meaning appeared is a hope in harmony people.

The next speech is as follows:

$$
\text { و اذنت مساجد، ورنت الكنائس }
$$

A piece of speech above is an informative thing that the boy said to Trump. Denotatively, this speech means the mosque pealed adzan as a call to prayer, as well as the church rung its bells. Position of the both are side by side and so close In addition, the context of this speech depicts when young children sit at dining table with Vladimir Putin (President of Russia), then walked to the window while pointing towards Al-Quds mosque and Church. As well as Barthes explanation that the first signification process where unity of marker and sign bring out a sign. In this context, the markers in the form of mosque and church, while the signs in the form of bells and adzan so that the appeared sign is time for worship.

It is different from connotative meaning that appeared in speech. When it involves elements outside the text, the setting shows that both worship places of two major religions are mutually exclusive. The resulting sign is form of religious harmony, and implicitly meaning shows hope for religious harmony.

This signification refers to development of speech expressions which showed that there is no barrier between Al-Aqsa mosque and Holy Church. In addition, expansion of content is obtained when child uttered a hopeful lament while holding Putin's hand toward the window to see a symbol of peace, it is mosque and church. Here are, connotation meaning appears that actualization of the metaphor of harmony appears in Palestine through the peace between two religions are Islam and Christianity.

Next is the speech as follows:

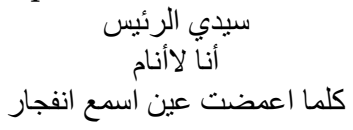




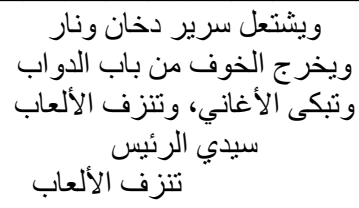

Similarly, the speech earlier which a piece of speech above is a declarative sentence because it shows a piece of information. This speech reflects story of child who could not sleep well because he always be listened by explosion sound. The denotation meaning obtained in 1-3 sentences which a child always listens to the explosion sounds, sees flames and smoke everywhere so that he cannot sleep peacefully. In addition, this meaning is strengthened by subsequent speech which mean that crying sound becomes a hum that he always listens to. Thus, first level semiotic meaning shows the outpouring of child's heart about his situation. This is certainly in accordance with Barthes' semiotic concept that refers to literal meaning.

After knowing the denotation meaning of the speech, researcher found an expansion of content. It is actualization of the denotation meaning is supported by a contextual representation that describes a boy who pour out his heart to Kim Jong Un in a room that burnt by the explosion. Existence of supportive background setting further strengthens the marked to bring out connotative meanings. The speech above shows the connotation that child lives in unsafe condition, his house is victim, his homeland is being threatened. He expressed his fear of the president of North Korea as a form of voice people wanted to hear.

On the other hand, the words "explosion, fire, smoke, cry and blood" are in speech above showed a symbol of chaos, anxiety, and even fear of Palestinian people with what happened yesterday, now, and tomorrow. In addition, the speech shows a proairetic code that explains series of events which took place to ruin the homeland. This entity meaning is suitable with Barthes' statement (Rusmana, 2014, p.187) that the world is full of signs, not just a simple meaning behind letters of alphabet. This is why the second level of significance is necessary.
As for significance in subsequent speech is as follows:

$$
\begin{aligned}
& \text { سبدي الرئيس } \\
& \text { نحن الحاربون، نحن المبعدون الرين } \\
& \text { نحن المذنبون، نحن المتهمون بالعبادة بالعبادة العباد } \\
& \text { المحكو مون شتقا بالعبادة التئاد } \\
& \text { الذين قطعت ألسنتنا } \\
& \text { لأنها نطقت بالثهادة بالثهادة }
\end{aligned}
$$

A piece of speech above shows declarative sentences in the form of passive voice. The marker is indicated by word "we" then the marked appears after it, until appearing a sign. In this step, significance is done denotatively, they are discriminated which this meaning is reinforced by the words,

$$
\text { "الحاربون ،المبعدون ،المذنبون ،المحكومون" }
$$

All these contained in speech. This meaning is obtained because it only refers to text without considering other elements outside the text (Yulianti, 2017, pp.17). All speech above child statement to a President of North Korea (Kim Jong Un). A declarative expression about what Palestine happened. This is first signification process happen.

After first level of significations over, Barthes continued signification process at second level to find connotative meaning in speech above. Based on the resulting denotation meaning, there is an expansion of content that involves elements outside text. Representation of context is background setting in Burma which becomes semantic code because there is hidden meaning there.

Implicitly, a piece of speech above describe reconstruction of Myanmar refugees who are looking for refuge and protection places. They are in discrimination condition on behalf of religion, even getting harsh attitude for what they believe. The manifestation of violence as known as dehumanization form on behalf of religion. It is suitable with Barthes' explanation (Rusmana, 2014, p.212) that relationship is dynamic and the functions is developing signs as result of sign openness. Thus speech arrived at second level semiotic meaning process.

The meaning of next speech is as follows:

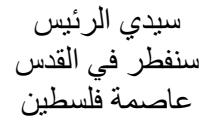




$$
\text { يكتبها رب الأمنيات العالقة بين ياليت وآمين }
$$

A piece of speech above is last statement in video "Sayyid el-rais". It is imperative speech that showed fasting invitation in Quds. As the speech clearly stated, "O president, we will break the fast in Quds". In addition, the speech is continued with declarative sentence in the form "capital city of Palestine" which clearly provided information that Al-Quds is capital city of Palestine. Denotatively, it means that there will be an agenda of fasting together in the Quds as capital of Palestine. As well as Barthes' semiotic ideas (Hidayat, 2018, pp.176) where denotation meaning is result of simple significance. It refers to textual and explicit meaning of text. Thus speech above showed denotative meaning as first-level meaning.

Continues to the next meaning, namely connotation meaning. In this case, the speech implicitly shows voice of Palestinian people who declare for the claim of Al-Quds as capital of Palestine so that this speech implies that Al-Quds is part of Palestine and nothing else. In addition, developing relationship is showed by context which describe a boy goes to a cell to approach girl. The girl is a prisoner, and she is helped by the boy then they ran towards Al-Quds with joy. Not only that, the subsequent speech also strengthened Palestinian hopes for Al-Quds. Implicitly, this speech explains that Quds is a city that is sanctified by Islam because Allah will grant every prayer of his servant there. An affirmation of colonial nation for the struggle for Al-Quds. Based on this speech, there is symbolic code in the form of Al-Aqsa mosque as representation of Al-Quds. As well as Barthes' explanation (Rusmana, 2014, p.209) that there are codes that operate in the text. Code indicates combination of signs in the text. Like the code above, which refers to the symbol of Al-Aqsa mosque which is repeatedly presented in video speech. Thus, the speech above arrived at second level of significations, namely connotation meaning of Barthes' perspective.

Based on the results of analysis above, the researcher revealed the results of signification based on Barthes concept of thought, namely first order and second order which are represented in two levels of meaning, namely denotation, and connotation. However, these findings do not stop here, but there is one concept that makes Barthes' characteristics different from other semiotics experts, namely myth concept that is carried in the masterpiece entitled Mythologies (1957).

\section{Myth of Religious Intolerance}

Based on the analysis of speech contained in "sayyid el rais", speech has significant process based on Barthes concept. This significance process produces two levels of meaning, called denotative and connotative meanings. Generally, this speech shows Palestinian voice as well as protest form aimed at pioneer of world. Here are further identification is needed to develop connotative meanings and find myth behind the expressed speech.

In this level, retroactive reading as medium for finding ideology that attached to connotation or well known as myth. Here are the reader has active role in expressing ideology contained in the speech. In the opening speech, there is hermeneutic code that is indicated when a boy invites United States president to fast with him. Further, there is emphasis on the following two sentences which describe house, bread, and broken heart. That statement clearly leaves puzzle where invitation culminates in lament.

In this context, there is reflection of religious intolerance contained in speech. It can be proven in metaphor shown in speech "Ramadan Kareem". An era is glorified by Islam and synonymous with breaking (ifthar). Ifthar is not only interpreted as banquet but the meeting of individuals in one assembly. A moment of strengthen friendship. As same as fasting invitation toward Trump is form of religious tolerance to create peace. As explained by Tillman (2004, p.95) that tolerance exists when individuals respect plurality. Here are religious tolerance concept is built to criticize world leaders about reality happened in Palestine. There is intolerance meaning in speech above that represented through author's imagination in building metaphor how beautiful religious tolerance. 
In addition, element of tolerance is described as attitude of mutual understanding and respect each other, either individually or collectively, so that peace can be realized. In other words, the author wants to convince positive effects from tolerance.

Not only that, the other one demonstrates myths of religious intolerance are:

$$
\begin{aligned}
& \text { سيدي الرئيس واذنت مساجد، ورنت الكنائس } \\
& \text { جير الن في الله، وأبو اب بلا حارس }
\end{aligned}
$$

This speech clearly shows binary opposition where both worship of two major religions, namely Islam and Christianity. They are side by side, although in reality they are inversely related. In this context, it is clear that proximity of two sacred places, namely Al-Aqsa mosque and Holy Church as symbol of religious harmony. On the other hand, the speech has opposition meaning that shows portrait of Palestinian people hopes towards religious harmony. This is why the speech is pinned on religious tolerance value where tolerance is interpreted as attitude statement that has positive impact (Bakar, 2015, pp.124).

Although the speech is just an imagination that implicitly presented by Author.

As well as this statement, phenomenon that carried in video has historical review. There is phenomenon as background for emergence of this video. Coinciding in 2018, Palestine is shocked by US action which placed embassy in Jerusalem and declared it as capital of Israel (BBc, 2018). Thus, the speech clearly has implicit meaning to be shown to the reader.

The speech which demonstrates tolerance is as follows:

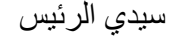

$$
\begin{aligned}
& \text { سنفطر في القدس الرس } \\
& \text { عاصمة فلسطين } \\
& \text { يكتبها رب الأمنيات العالقة بين ياليت وآمين }
\end{aligned}
$$

A piece of speech above shows religious tolerance value where speech is not merely statement that Al-Quds is capital of Palestine, but there is religious ideology prevails. In addition, there is symbolic code that addressed through word "Al-Quds" repeatedly presented in the video. This clearly shows how important the city is to Palestinian people. As well as mythical concept promoted by Barthes (1973, p.95), conventionally $\mathrm{Al}$-Quds is a city that is highly venerated by three major religions are Islam, Judaism and Christianity. That's why myth is an ideology that accepted by society because it considers cultural aspects in its implementation.

Indirectly, speech above contradicts reality about Al-Quds. Nowadays Al-Quds is still a dispute land that is contested by three major religions. The tolerance concept that is carried becomes an insinuation as well as voice of the Palestinian people who yearn for their homeland. As Forst (William \&Waldron, 2008, p.80) states that tolerance is present as an alternative to avoid conflict. Harmony views between minorities and majority on social peace that tolerance offers. In other words, tolerance can be an alternative in resolving disputes on large scale, especially the state.

Based on connotative development of some speech in Sayyid El-Rais' video, the researcher are increasingly convinced that the figures presented are reflections of religious intolerance. It implicitly represented through speech that are hopeful, grievous, or imaginary as representation form of Palestinian voice that are not heard. Through narrative above, author has high hopes which his work can increase individual awareness and empathy for the Palestinian state.

\section{CONCLUSION}

Based on semiotic analysis result of Barthes' perspective in the video of Sayyid El-Rais, it can be concluded that there are two levels of meaning found in speech, namely denotative and connotative meaning. First level of significance produces some codes that refers to text structure including; symbolic, semantic, and hermeneutic. Denotatively, speech in that video reflect outpouring of Palestinian child about what happened to him called deprived homeland. The second level reading that refers to code development resulted in amyth of religious intolerance. In connotative, there are portraits of religious intolerance are carried in video. Reflections on religious intolerance can be shown 
through implicit meanings in speech such as expectations about religious harmony, mutual respect, and peace among countries, sad lamentations. Thus, the speech present as representation of religious intolerance felt by Palestinian people, so that the author's message that can be taken through this. It increases awareness of religious tolerance and empathy for others as a form of humanity.

\section{REFERENCES}

Abdullah, M. (2001). Pluralisme Agama dan Kerukunan dalam Keragaman. Penerbit Buku Kompas.

And, M. S. W., \& Waldron, J. (2008). Toleration and Its Limits. Cambridge University Press.

Anonim. (2018). Presiden Trump tidak akan hadir dalam pembukaan Kedubes AS di Yerusalem. $\mathrm{Bbc}$ Indonesia. https://www.bbc.com/indonesia/dunia44035112

Bakar, A. (2015). Konsep Toleransi dan Kebebasan Beragama. TOLERANSI: Media Komunikasi Umat Bergama, vol 07, no, 1-9.

Barthes, R. (1973). Elements of Semiology. Hill and Wang.

Birowo, M. A. (2004). Metode Penelitian Komunikasi. Gitanyali.

Cohen-Almagor, R. (2006). The Scope of Tolerance: Studies on the costs of free expression and freedom of the press (Extremism and Democracy). Routledge.

Goldie, M. (2010). John Locke: A Letter Concerning Toleration and Other Writings. Liberty Fund, Inc.

Hasyim, U. (1979). Toleransi dan kemerdekaan beragama dalam Islam sebagai dasar menuju dialog dan kerukunan antar agama. PT. Bina Ilmu.

Hidayat, W. (2018). Representasi Makna Ideologis Kisah Ashab Al-Kahf: Analisis Semiotikaa Roland Barthes dalam Surah Al- Kahf. Mutawatir: Jurnal Keilmuan Tafsir Hadith, 08, n, 170-190.

Horton, J. and S. M. (1985). Aspects of toleration: Philosophical Studies. Methuen.
Ismail, M. S. (2003). One True God: Resiko Sejarah Bertuhan Satu. Penerbit Qalam.

Kamus Besar Bahasa Indonesia. (n.d.). Kemendikbud. Retrieved January 13, 2021, from https://kbbi.kemdikbud.go.id/entri/toler $\% 0$ Aan.

Kriyantono, R. (2006). Teknik Praktis Riset Komunikasi. Prenada Media Group.

Masduqi, I. (2011). Berislam Secara Toleran: Teologi Kerukunan Umat Beragama. Mizan.

Munawir, A. W. (n.d.). Kamus Arab Indonesia alMunawir. Balai Pustaka.

Nicholson, P. P. (1985). Toleration as a Moral Ideal. Cambridge University Press.

Nugraha, R. S. and S. U., \& Kasanah. (2019). Perspektif Islam Terhadap Nilai Moral Dalam Cerpen Daulah Al- 'Ashāfīr Karya Taufīq Al- Chakīm (Analisis Semiotikaa Roland Barthes). Jurnal CMES, 12, $n$.

Obsorn, K. (1993). Tolerance. The Rosen Publishing Group, Inc.

Rosyadi, M. I. (2018). Ajak Trump Bukber di Palestina. Detik.Com. https://inet.detik.com/cyberlife/d4032335/ajak-trump-bukber-di-palestinaiklan-ramadan-ini-viral.

Rusmana, D. (2014). Filsafat Semiotikaa (Paradigma, Teori, dan Metode Interpretasi Tanda: Dari Struktural hingga Dekonstruksi Praksis). CV Pustaka Media.

Sobur, A. (2006). Semiotika Komunikasi. PT Remaja Rosdakarya.

Sobur, A. (2018). Analisis Teks Media. PT Remaja Rosdakarya.

Sugiyono. (2008). Metode Penelitian Pendidikan Pendekatan Kuantitatif, Kualitatif, RED. Alfabeta.

Tillman, D. (2004). Pendidikan Nilai Untuk Kaum Muda Dewasa. Grasindo.

Vera, N. (2014). Semiotika Dalam Riset Komunikasi. Ghalia Indonesia.

Yulianti, F. D. dkk. (2017). Representasi Maskulinitas Dalam Iklan Televisi Pond's Men \#Lelakimasakini (Analisis Semiotikaa Roland Barthes Terhadap Representasi Maskulinitas). Jurnal Komunikasi, 09, $n$.

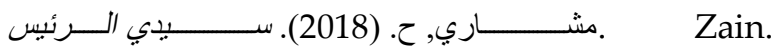


LANGUAGE CIRCLE: Journal of Language and Literature, 16(1) October 2021

https://www.youtube.com/watch?v=JIJB7c

v97Dg 